\title{
WHOI $-75-28$
}
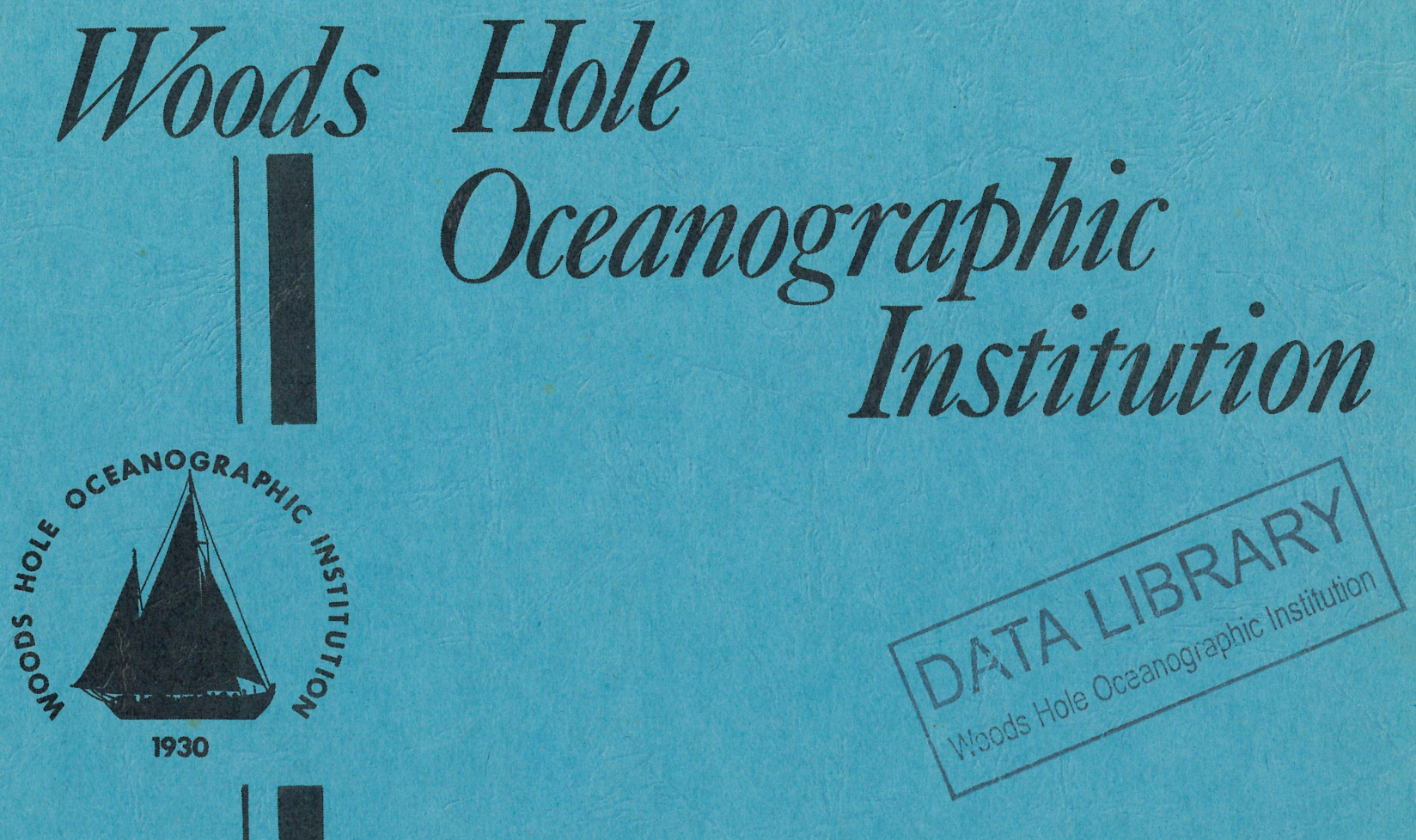

ARPA ROCK DRILL REPORT

by

Raymond E. Davis, David L. Williams and Richard P. Von Herzen

June 1975

TECHNICAL REPORT

Prepared for the Office of Naval Research under Contract N00014-75-C-0681; NR 294-017. Approved for public release; distribution uniimited.

WOODS HOLE, MASSACHUSETTS 02543 
WHOI $-75-28$

ARPA ROCK DRILL REPORT

by

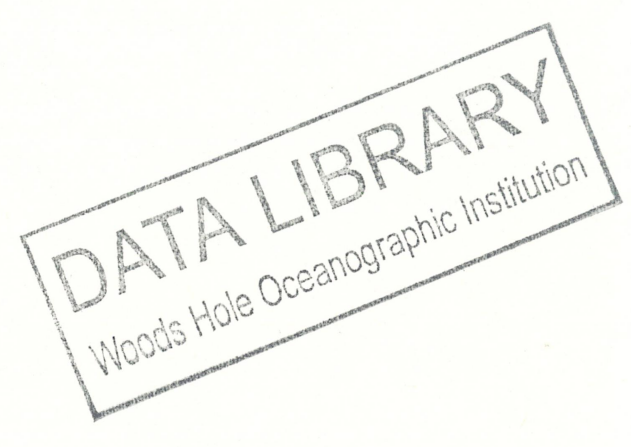

Raymond E. Davis, David L. Wi Tliams and Richard P. Von Herzen

WOODS HOLE OCEANOGRAPHIC INSTITUTION

Woods Hole, Massachusetts 02543

June 1975

TECHNICAL REPORT

Prepared for the Office of Naval Research under Contract N00014-75-C-0681; NR 294-017.

Reproduction in whole or in part is perritted

for any purpose of the United States Goverment. In citing this manuscript in a bibliography, the reference should be followed by the phrase: UNPUBLISHED MANUSCRIPT。

Approved for public release; distribution unlimited。

Approved for Distribution

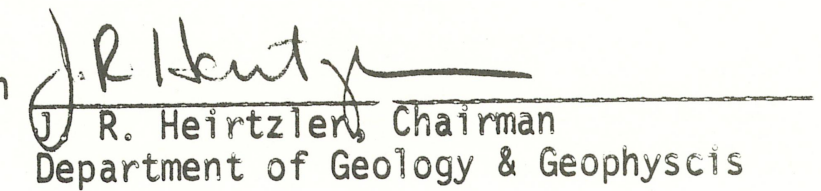




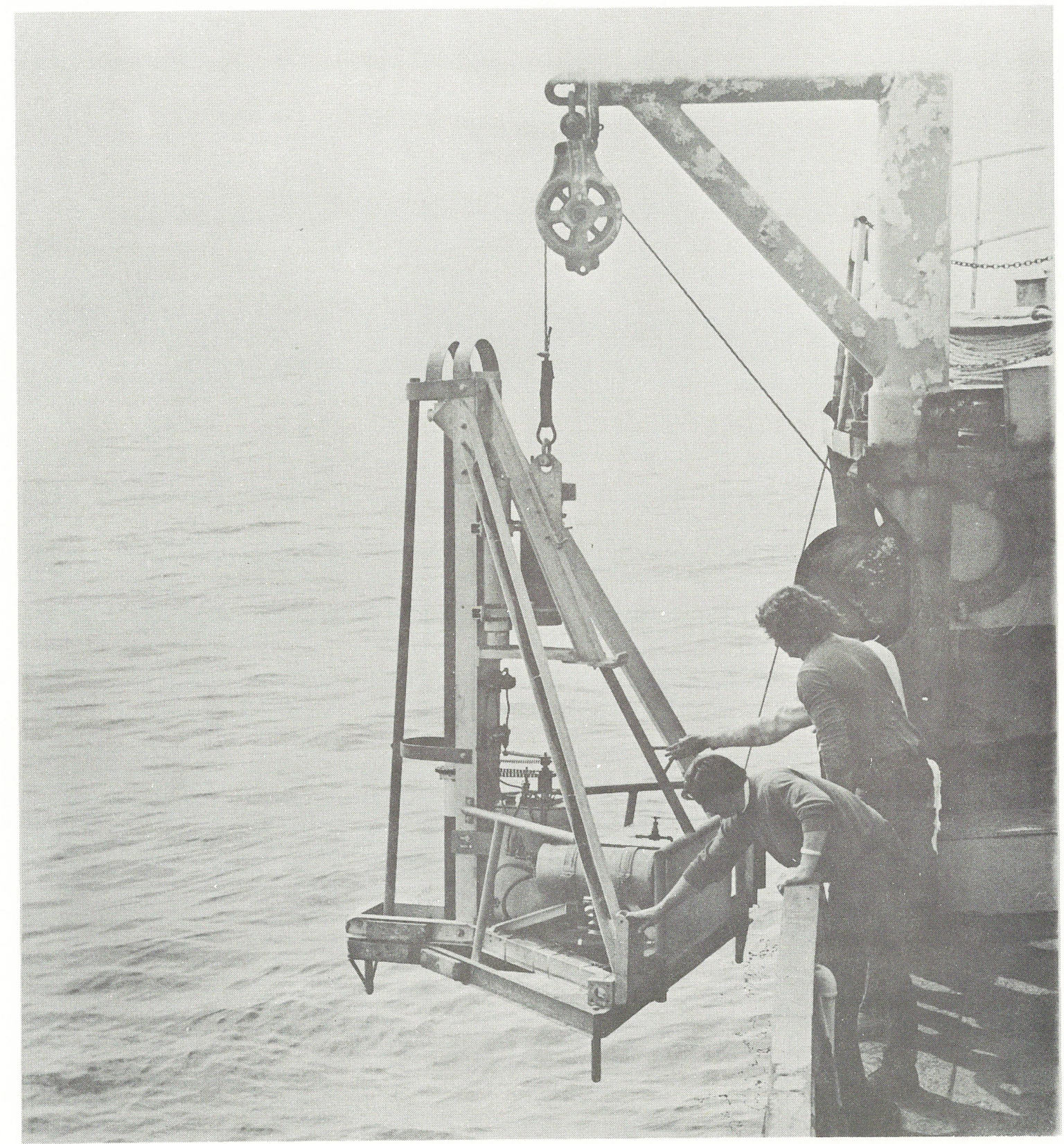

"Deploying the Rock Drill from the R/V GOSNOLD, Gulf of Maine, September 1973." 


\section{Table of Contents}

Abstract

I. Introduction. . . . . . . . . . page 1

II. Background and Development. . . . . . . . 1

II. Present System Design . . . . . . . . 3

IV. Operational Description . . . . . . . . 6

V. Future Plans. . . . . . . . . . . 7

VI. General Specifications and Engineering Data • 8

VII. References. . . . . . . . . . . 11

Acknowledgements. . . . . . . . . . 12

Illustrations . . . . . . . . . . 13-29 


\section{Abstract}

This report outlines the development and capabilities of the Woods Hole Oceanographic Institution's Rock Core Drill. The Rock Drill is shown to provide a relatively inexpensive means of recovering oriented bottom rock samples from the oceanic crust for magnetic and petrochemical studies. It is completely self-contained and capable of recovering $1 \mathrm{~m}$ long, 3/4-inch diameter, rock cores from depths to $4000 \mathrm{~m}$. Most efficient deployment is from a surface vessel, but with sufficient modification it is capable of being safely transported by a DSRV. 


\section{Introduction}

Except for occasional and expensive corings such as JOIDES Deep Sea Drilling Project, in situ oriented hard-rock samples from the oceanic crust are relatively unknown. This type of sample can provide useful information on the magnetic and petrochemical properties of sea-floor rocks, effects of sea-water interaction, and the bearing strength of the seabed. In addition, measurement of the Earth's heat flow through the ocean floor is at present feasible only in sediments. The use of a deep-sea rock drill has obvious advantages over normal dredge sampling methods for all of these investigations.

The WHOI Hard-Rock Core Drill is a fully automatic self-contained under-sea corer, deployed on the ocean bottom either by surface vessel or deep submersible. It is capable of recovering $1.9 \mathrm{~cm}(3 / 4$ inch) diameter rock cores up to $1 \mathrm{~m}$ ( 3.3 feet) long, penetrating up to $1 \mathrm{~m}$ (several feet) of sediment overburden if necessary. Both shallow and deep water coring have proven successful at drilling rates exceeding $5 \mathrm{~cm}$ ( 2 inches) per minute.

Testing at sea has included thirteen surface vessel lowerings to depths of $400 \mathrm{~m}$ (1200 ft) in the Gulf of Maine during the summer of 1973, with seven rock cores recovered; only minor drill malfunctions occurred. More recently the drill was used to successfully sample six sites in the Mid-Atlantic ridge during FAMOUS operations in the summer of 1974. Four usable, oriented rock cores were recovered from depths in excess of $2700 \mathrm{~m}$ $(9000 \mathrm{ft})$. The longest measured $41 \mathrm{~cm}$ (see Fig. I).

\section{Background and Development}

Although originally built for deployment from the DSRV ALVIN, the drill in its present form is modified for lowering from a surface vessel. The earlier development work included ALVIN dives off New Providence Island in the Bahamas and in Woods Hole harbor in the Spring of 1972, which demonstrated the capacity of ALVIN to safely operate with the drill (see Fig. 2). Whereas the drill was 
considered operational at that point, intermittent failures indicated a need for further engineering and testing. In addition, it was felt that the drilling function could be optimized to recover longer cores through careful study of the drilling parameters (bit loading and speed) and the bit configuration itself.

The drill was designed in part around the mining industry"s XRT diamond coring bit. These bits, in their standard configuration of 40 to 60 stones per carat, 3 carats per bit, are most efficient using a 550-700 kg (1200-1500 pound) download force. Industrial cutting rates using this optimum bit loading, have exceeded 10-15 cm (4-6 inches) per minute for holes up to $5 \mathrm{~m}$ ( 15 feet) deep. A $700 \mathrm{~kg}$ loading, however, is some 4 or 5 times that available when limited by the payload capacity of ALVIN. Early dockside testing using smaller downloads of $138-160 \mathrm{~kg}(300-350$ l.bs $)$ demonstrated relatively poor drilling rates and greatly reduced bit life due to smoothing of the individual diamonds. Weight of the drill in water was then approximately $270 \mathrm{~kg}$ (590 lbs).

For surface ship deployment, a maximum air weight of $900 \mathrm{~kg}$ (2000 lbs) was settled upon to keep shore and shipboard handling problems to a minimum. This allowed ballasting in close proximity to the bit and increased the underwater bit loading to $250 \mathrm{~kg}(550 \mathrm{lbs})$ at tilt angles up to $15^{\circ}$, and to $300 \mathrm{~kg}(650 \mathrm{Ibs})$ on a level surface. Bits with forty and sixty stones per carat were now found to perform somewhat better: however, those with 100 stones per carat showed the greatest improvement in both drilling rates and life. (See graphs 1, 2 and 3). Initial driling rates in excess of $10 \mathrm{~cm}$ ( $4 \mathrm{in}$ ) per min. were obtainable, with a net rate of over $5 \mathrm{~cm}$ ( 2 in) per min. for $1 \mathrm{~m}(40 \mathrm{in})$ cores. A $1 \mathrm{~m}$ core length seems to approach the upper limit, since the main batteries are able to produce only 20-24 minutes power of sufficient voltage to maintain bit rotation.

Although most of the test coring was in granodiorite (see Fig. 3 and 4 ), the smaller number of basaltic samples tested exhibited little difference in drillability

(see Fig. 5). Basalt did appear more brittle, however, 
and on one occasion fractured and jammed the bit to prevent further penetration. As a result of this work, the bits used during the FAMOUS study were chromium-plated on their inner diameters to provide a smoother surface, and there was no recurrence of jamming problems.

\section{Present System Design}

The present configuration and weight of the drill enables it to be utilized from a surface vessel with optimum cutting efficiency. The requirements for satisfactory drill deployment and recovery include a crane and winch system of sufficient capacities, along with a graphic recorder to display the $12 \mathrm{kHz}$ telemetered data and approach to bottom from echo ranging. Some method of ship positioning over the drill site is also necessary to prevent dragging over the bottom or bending of the core barrel before retraction. Bottom navigation systems have been employed in deeper water, and in the Gulf of Maine a tethered buoy marked the area of investigation. A simple schematic and working drawing is presented in Figure 6 showing the seven related subsystems as described below:

\section{Drive Subsystem:}

The prime mover is a standard 36 VDC electric motor rated at $3 \mathrm{KW}$ and $1550 \mathrm{rpm}$ in air. With minor modifications, this motor is capable of delivering over 4 HP while operating in its own pressure compensated oil-filled housing. It has been tested to 6000 psig, and rotates the drill barrel and pumps via chain drive at $600 \mathrm{rpm}$, while drawing 110 amps. A separate 1/4 HP 36 VDC motor and pump combination, housed in its own pressure compensated oil-filled housing, is energized for core retraction and draws 10 amps.

This separation of drilling and retraction motors permits retraction of the core barrel long after the main batteries might be too discharged to power the drill motor. It also allows for core retrieval without rotation, making possible a reliable determination of the original core orientation. 


\section{Power Subsystem:}

Power to drive the 36 VDC main motor and retract motor, as well as the 12 volt solenoids and 24 volt instrument relays, is derived from three high capacity 12 VDC automobile batteries (see Fig. 7). Connected in series, they are contained in their own oil-filled box along with the 12 volt main- and retract-motor solenoids and wiring bus. A relief valve prevents excessive pressure build-up due to battery gassing and the compensation bladders allow for the unavoidable air pockets and compression of the oil that would become a problem at depth. The oil-electrolyte interface is maintained by the non-miscible properties of the two liquids and by using an oil (Exxon"s Marcol) of significantly lower specific gravity.

\section{Frame Subsystem:}

The aluminum channel frame (6061-T6) provides the stable platform for the mounting of all the drill components, and retains the light weight required to be compatible with ALVIN"s payload. It was designed to minimize drilling vibration and to reduce the drill mass moment with respect to ALVIN's center of gravity. For use from a surface vessel, a steel channel sub-frame has been added with additional lead ballasting for proper balance and increased bit loading. This structure also provides the needed protection for surface deployment over rough bottom terrain (see Fig. 8).

\section{Drilling subsystem:}

The drilling system utilizes a modified diamond set rotary bit of XRT size designation, which bores a $2.94 \mathrm{~cm}$ (1.155 inch) diameter hole and retrieves a $1.90 \mathrm{~cm}$ (.735 inch) diameter core (see Fig. 9). The bit, core retainer, and double tube rigid barrel are standard in the mining industry and of proven reliability. The upper end of the core barrel is attached to the piston, which is constrained to rotate with the drill barrel but free to 
move in a vertical direction. Two positive displacement pumps, chain driven by the main motor, provide flushing fluid and down-load pressure. Both are capable of supplying up to 8 1/M (2 GPM) at 6.8 bars (100 psi). using filtered sea water as the working fluid.

To provide bi-directional sealing at the pistoncylinder interface, a Parker "T"-seal is used, which has the added advantage of keeping break-out and running friction forces to a minimum (see Fig. 10). Also, the aluminum drill barrel has undergone a hard-coat anodizing and commerical sealing process to provide a hard, smooth running surface for the piston and seal.

\section{Control Subsystem:}

The original drill control unit employed a crystalcontrolled oscillator and count-down chain. Cosmos logic elements generated the various control signals which in turn operated the control relays. This highly sophisticated circuitry proved troublesome and unreliable, however, probably because of the high power transients associated with operation of the drill motor and control solenoids.

The new control unit uses a small battery-powered DC timing motor that drives a series of cam-actuated microswitches to control the drilling and retract functions. The regulated power supply provides $+3 \%$ timing accuracy, and cam adjustments allow any desired range of cycle times from 20 minutes to 3 hours (see Fig. 11).

Control function may be initiated 1) directly by the timing circuit, 2) by some drill status sensing device, such as a bottom switch, 3) or by tactile command from a submersible. The primary control to date has been the timing circuit as described above, which has an initial delay period to allow drill positioning, then a drilling sequence, a second delay to allow some main battery recovery if necessary, and lastly, core barrel retraction. The length of the functions are preset prior to initiating the sequence and are determined by depth, bottom terrain, length of core desired, etc. 
Monitoring and Data Collection

Main battery voltage information is fed into an acoustic telemeter and relayed aboard the surface ship to give real-time data as to drill status, rate of energy expediture, power remaining, etc. For surface deployment, a voltage dividing circuit with a tilt switch reduces the data signal voltage if the drill tilts more than $15^{\circ}$ from the vertical, indicating an unstable rate of descent, unacceptable bottom conditions or toppling of the drill during recovery. From the real-time graphic display of this information it is also possible to determine the proximity of the drill to the bottom and the approximate amount of drift of the surface ship from the drill site.

\section{ALVIN Attachment Subsystem:}

The ALVIN was able to launch, dive, uncouple, and jettison the drill in emergencies and then retrieve it and surface, all in moderate seas. A locking device restrained the drill while ALVIN was near the surface, then manually unlocked to allow safe deployment on the seabed. After recoupling, the drill was again locked to ALVIN on approaching the surface and during ALVIN's retrieval by the mother-ship. The system of coupling and uncoupling met all of ALVIN's safety requirements (see Fig. 12).

\section{Operational Description}

In actual operation, the drilling sequence allows sufficient time for lowering and positoning of the drill prior to bit rotation. Drilling begins as the main motor rotates the drill barrel and the download and flushing pumps. Download pressure is fed inside the drill barrel to the top of the piston, which rides vertically on the four torque rods fixed to the barrel at each end. The piston, and attached core barrel, telescope down the drill barrel with a rotary motion until full download pressure is reached. 
This force is imparted to the coring bit and maintained at a constant value by a pressure relief valve, regardless of penetration rate or tilt angle. Flushing fluid flows through the annulus formed between the inner and outer core barrels and washes and cools the bit until the drilling portion of the cycle is terminated.

After a short battery recovery period, the retract pump reverses the flow in the system and permits sea water ambient pressure to force the piston back up the barrel, thus extracting the core and core barrel from the bore hole. The drill is then winched back aboard the surface vessel. A total deployment time is typically 110 minutes in $2740 \mathrm{~m}$ (9000 ft) of water, with a 28-minute bottom time that includes 20 minutes actual drilling.

\section{Future Plans}

The WHOI rock drill is presently stored in a preserved condition, less expendables, pending disposition of several proposals on its future use.

A study of the Galapagos spreading center, much like the 1974 FAMOUS work, is being planned for 1976-1977 and may include bottom sampling with the rock drill.

Continued development and drilling programs should lead to recovery of longer cores over a wider range of bottom terrain; and effective utilization of heat-flow instrumentation might allow measurement of conductive heat-flow from the intrusion zone of a spreading oceanic ridge.

The inclusion of a simple attitude and azimuth recorder would more accurately define core orientation, and use of thin walled bits in a second generation drill. could eventually reduce the size and weight by half for optimum use with a DSRV. 


\section{General Specifications and Engineering Data}

\section{Drill Specifications}

Height

Width (fore and aft) (beam)

Weight (air) (water)

Power - 3 Sears Die-Hard Automotive 12 VDC (nominal) wet cells. 38 amp hours a 25 minute rate, $0^{\circ} \mathrm{C}$

Bit Loading (up to $15^{\circ}$ tilt)

Bit Rotation speed

Bit Size and Type

(100 stones/carat, 3 carats total, premium grade)

Bore Hole Diameter

Core Diameter

Drilling Fluid Flow Rate

Retract Rate

Max. Drilling Time

Avg. Drilling Rate

Core Recovery Capability

(with up to 1 meter sediment overburden)

Operating Depth
$2.9 \mathrm{~m}\left(9^{\prime} 6^{\prime \prime}\right)$

$1.5 \mathrm{~m} \mathrm{(5^{ \circ } 0 ^ { \prime \prime } )}$

$2.9 \mathrm{~m}\left(9^{\circ} 6^{\prime \prime}\right)$

$860 \mathrm{~kg}$ (1900 lbs)

$610 \mathrm{~kg}$ (1350 lbs)

36 VDC

$250 \mathrm{~kg} \quad(550 \mathrm{Ibs})$

$600 \mathrm{rpm}$

XRT diamond set

$2.94 \mathrm{~cm}$ ( 1.155 inches)

$1.90 \mathrm{~cm}$ (.735 inches)

$81 / \mathrm{M}(2 \mathrm{GPM})$

$1 \mathrm{~m} / \mathrm{min}$.

24 minutes

over $5 \mathrm{~cm} / \mathrm{minute}$

1 meter

30 to $4000 \mathrm{~m}$ 


\section{Telemetered Data}

Real Time information as to:

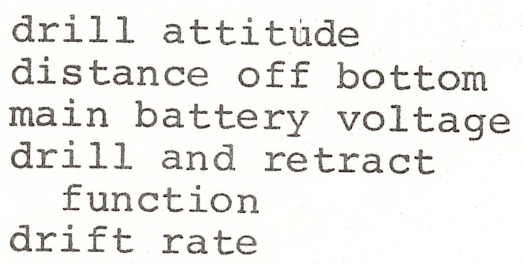

Dockside Test Data

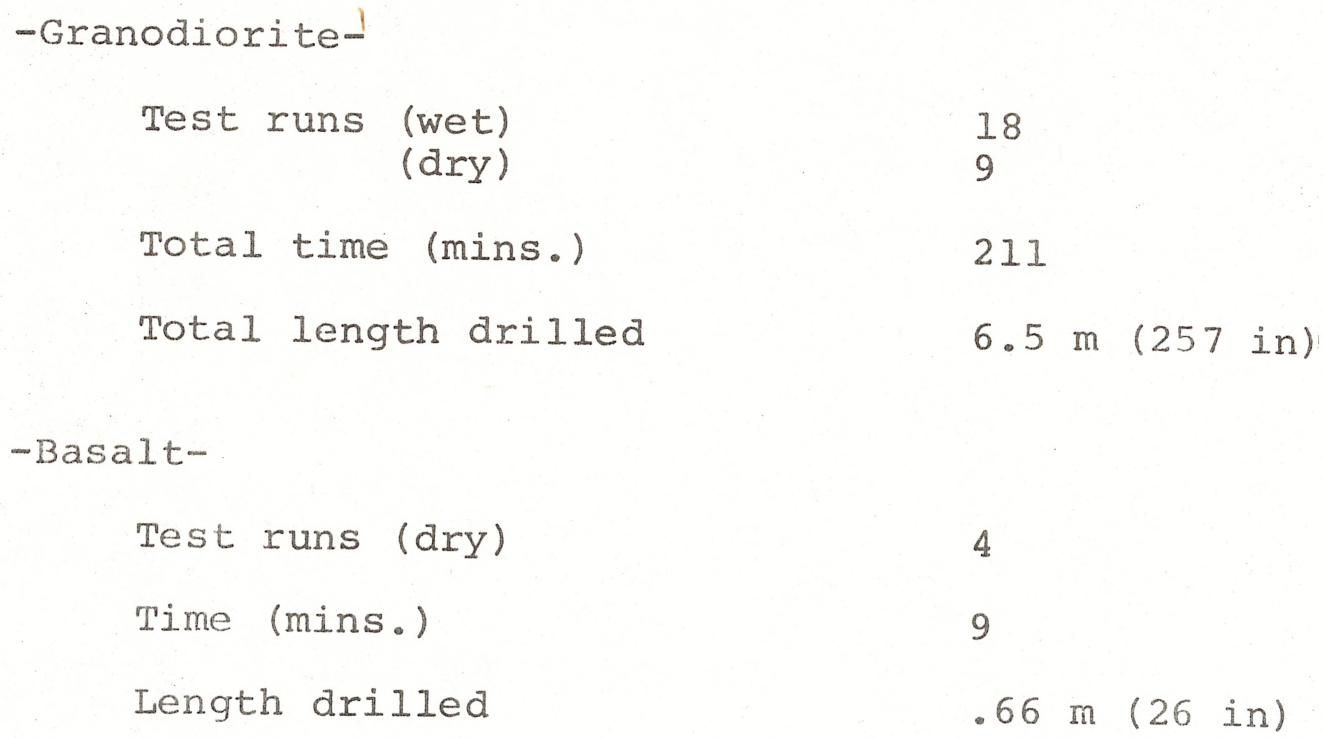




\section{Parts Specification}

Main Batteries - Sears Die-Hard, No. 27C.

Drill Motor - $3 \mathrm{KW}$ General Electric Kinematic $30 / 40$ with monel sleeve, epoxied armature, threaded commutator, carbon brushed.

Retract Motor - Westinghouse, I/4 HP, 32 VDC, Threaded commutator, carbon brushed.

Solenoids - Ford Motor Co., 12 VDC.

Retract Pump - Teel 1/8" carbon bearing rotary gear. Flush Pump - Teel 1/4" carbon bearing rotary gear.

Download Pump - Teel 3/8" carbon bearing rotary gear.

Pressure relief valve - Cash Acme back pressure regulator, type FRM-2.

Check valves - Nupro check valve, No. XY402-1, 1 psi. Main bearings - Fafnir ball bearing, sealed, No. $912 \mathrm{PP}$.

Bearing grease - Dow Corning silicone 44 .

Chain and Sprockets $-5 / 8$ and $3 / 8$ pitch, TEK Bearing Co. Seals - Parker "T"-seals, and Parker "0"-rings.

Bladder Accumulators - $150 \mathrm{cu}$. in. Buna-N, Kennett Corp. Pressure Compensating Fluid - Exxon's Marcol 52 (dielectric). Acoustic Telemeter - modified AMF model 1023, single channel. Control Timer - Eagle Signal TM series. Timer motor - A.W. Haydon, 6300 series. Control Power Supply - 1.5 VDC alkaline energizers.

Coring System - Christensen Diamond Co. XRT Bevel wall core bits, type 118091, PQ-100, chrome plated I.D.

RWT Double tube core barrel, $7 \mathrm{ft}$.

XRT Core lifter springs. 
VII. References

1. Ocean Systems, Inc., Affiliate of Union Carbide Corp. and the Singer Comp., Reston, Virginia.

2. Welling, C. G. Designing an Advanced Marine Corer: October 1970, Mechanical Engineering, pages 28-33.

3. Brooke, J. and Gilbert, R.I.G., A Deep Sea Rock Core Drill: 1968, Atlantic Oceanographic Laboratory. Bedford Institute, Report BI 1968-6, 95 pages.

4. Brooke, J. and Pelletier, B.R., Sea Drilling Techniques of the Bedford Institute: Sept. 1970, Underwater Science Technology Journal, Pages 165-167.

5. Winget, C.I., Hand Tools and Mechanical Accessories for a Deep Submersible: 1969, W.H.O.I. ReE. No. 69-32,
Pages 65-74.

6. Mason, R., A Rock Coring Drill: Sept. 1970, Oceanics Department, Vickers Limited, Report O. D. 19, 8 pages.

7. Crounch, D.S., Design Study for Lunar Exploration Hand Tools: Martin Marietta Corporation, Baltimore Division.

8. Christensen Diamond Products, Inc. Diamond Drilling Handbook, Second Edition, April 1970 . 


\section{Acknowledgements}

Much of the conceptual and early engineering design work of the Rock Drill was done by Mr. Barrie Walden of Ocean Engineering, Woods Hole Oceanographic Institution.

Mr. Walden was assisted by Mr. Andrew Barrs, a student in the joint MIT-WHOI graduate Ocean Engineering program. Mr. Barrs was largely responsible for designing and implementing the ALVIN attachment system and for the prototype Rock Drill development during its use as a DSRV tool.

Mr. Warren E. Berger of Christensen Diamond Products Co. greatly assisted us in arriving at the final drill bit configuration and contributed several further suggestions to help ensure success of the coring system.

Mr. Richard A. Zuck, a WHOI research assistant, contributed much time and effort during the later stages of drill development and bit testing, and provided invaluable assistance during the Gulf of Maine Sea Trials. 


\section{List of Illustrations}

Figure 1. $41 \mathrm{~cm}$ core recovered during FAMOUS, summer 1974.

Figure 2. AIVIN submerged with the drill.

Figure 3. Granodiorite test block.

Figure 4. Dock testing the coring system.

Figure 5. Small basalt sample.

Figure 6. Drill Schematic.

Eigure 7. Main battery box.

Figure 8. Overall picture of drill showing subframe in particular.

Figure 9. Close-up of drill bit.

Figure 10. "T"-seal with piston.

Figure 11. Control unit.

Figure 12. Drill on ALVIN

Graphs 1, 2, and 3 show penetration rates of different bit configurations for varying downloads. 


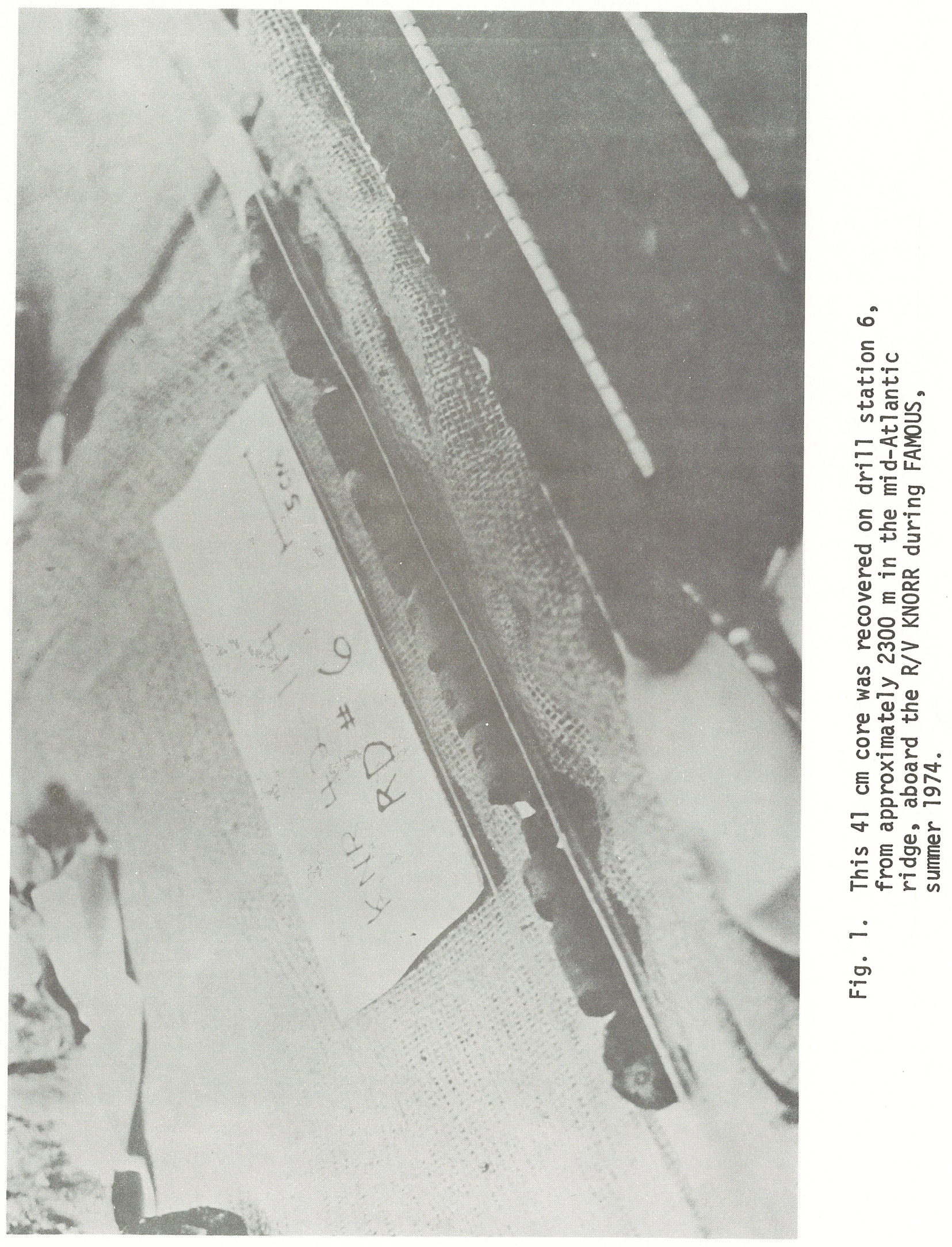




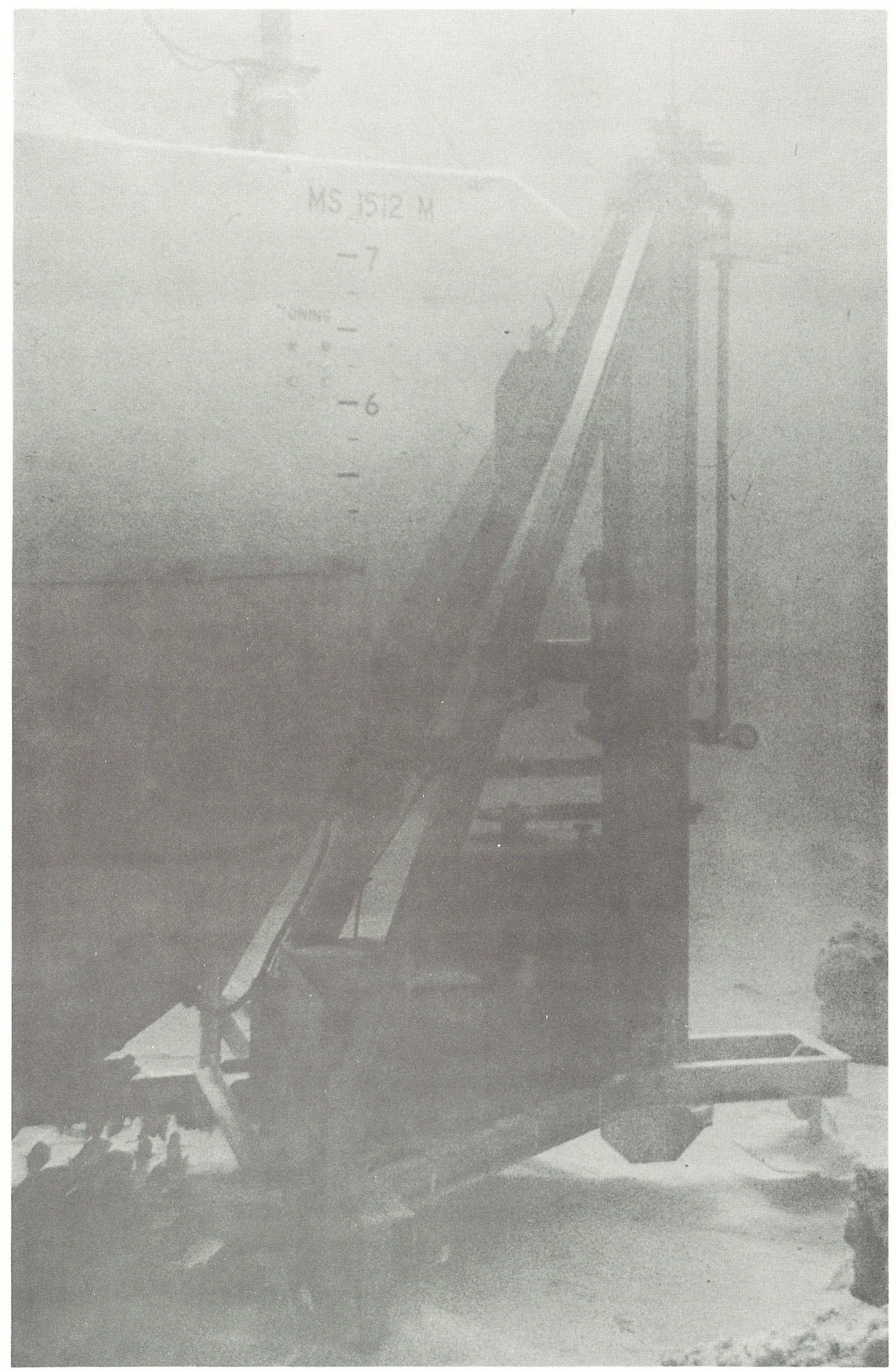

Fig. 2. The DSRV ALVIN with the drill, in its original configuration, submerged at $100 \mathrm{ft}$. prior to test drilling. 


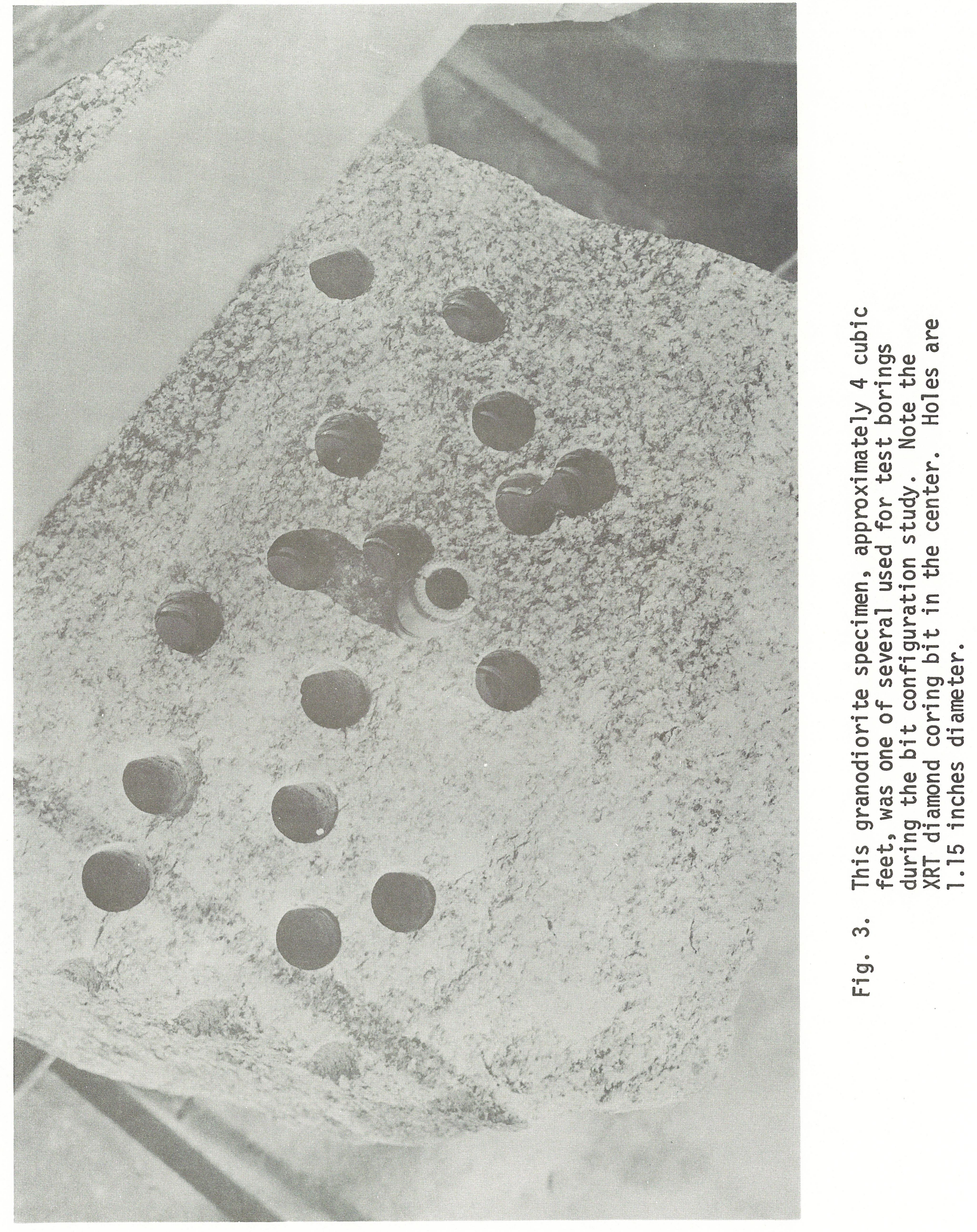




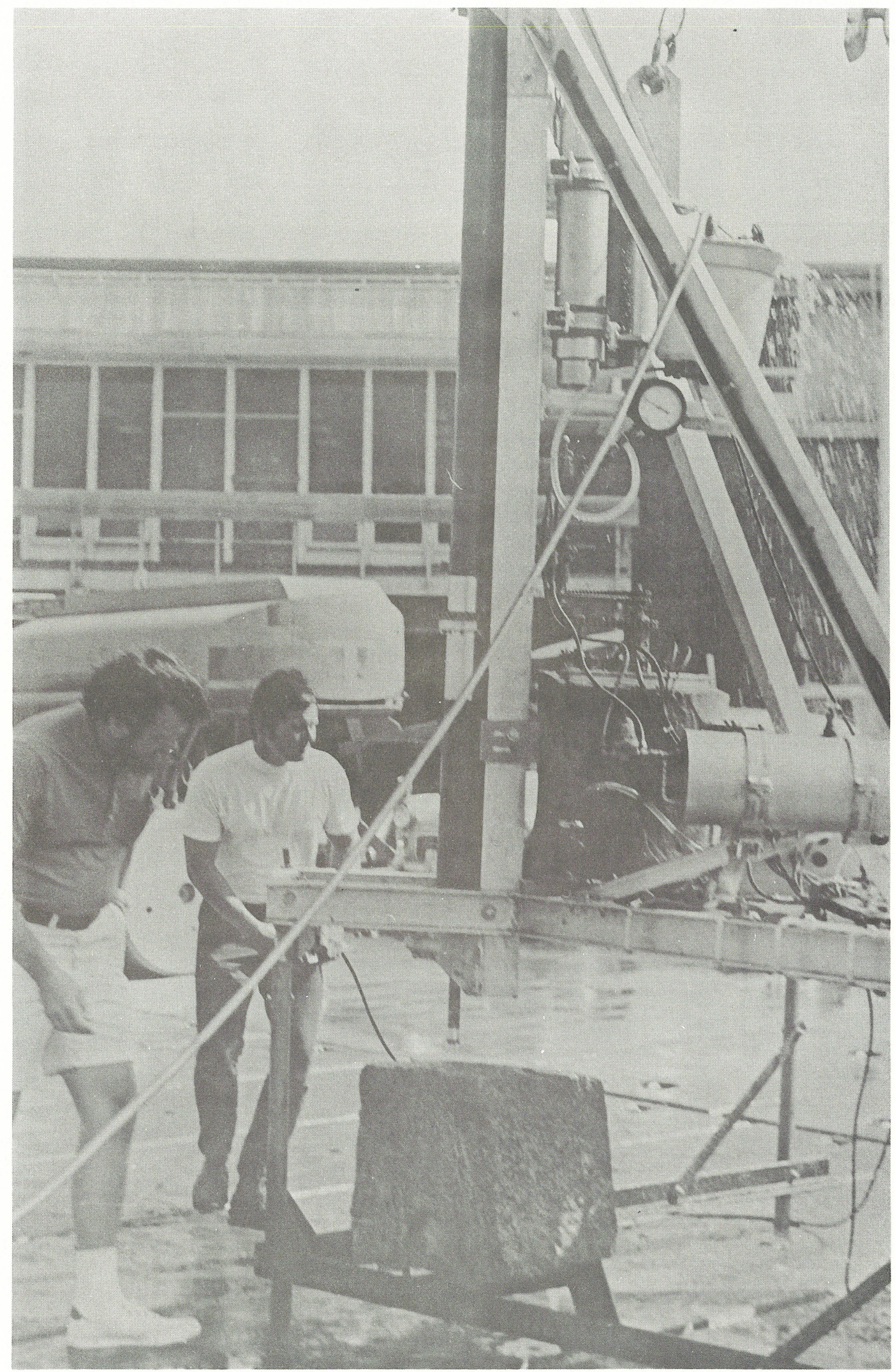

Fig. 4. Dry running of the drill to allow closer observation of bit testing on the W.H.O.I. dock. Note granodiorite specimen suspended beneath drill. 


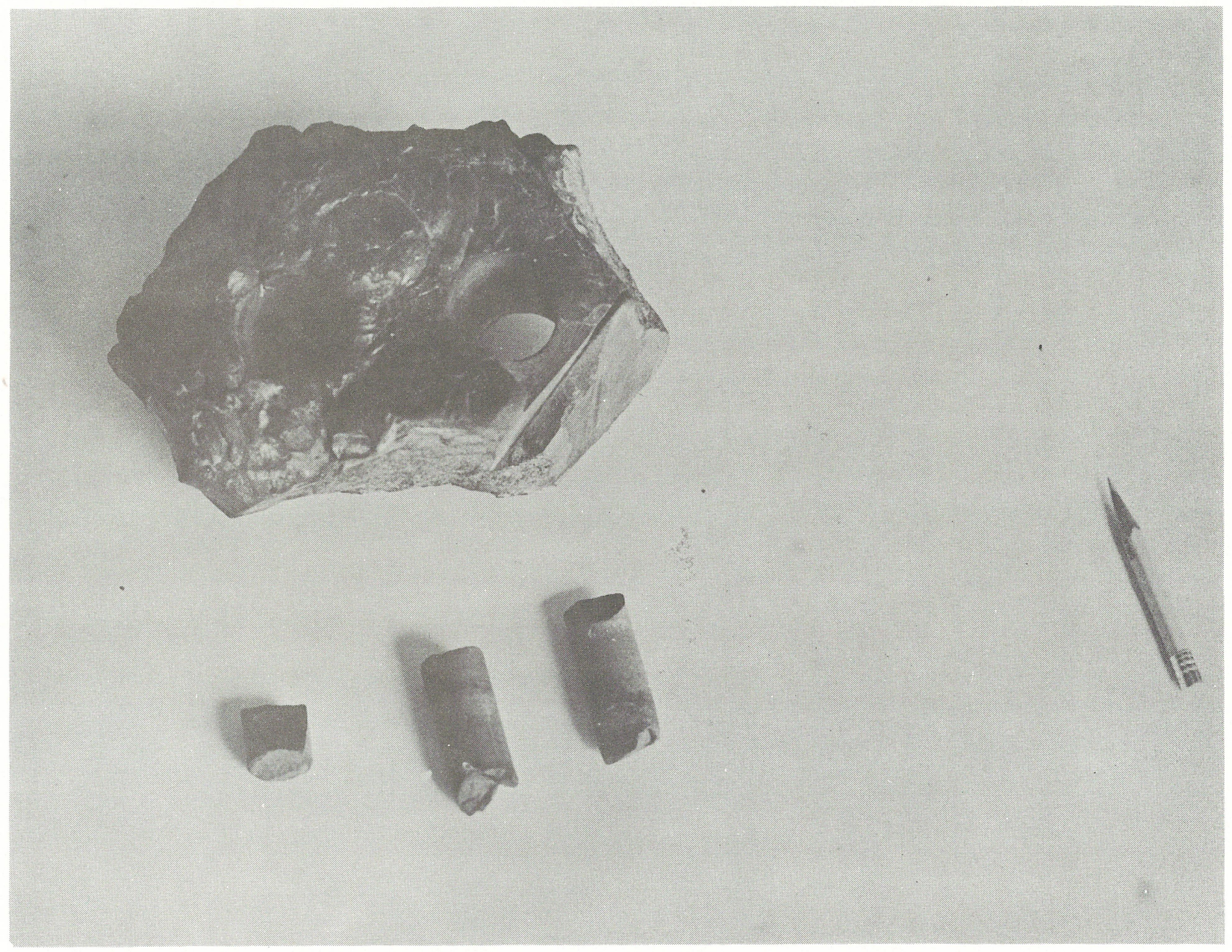

Fig. 5. This oceanic basalt specimen yielded two 3/4-inch diameter cores. The smaller plug at the left illustrates the tendency of basalt to fracture. 
ROCK DRILL

WORKING SCHEMATIC

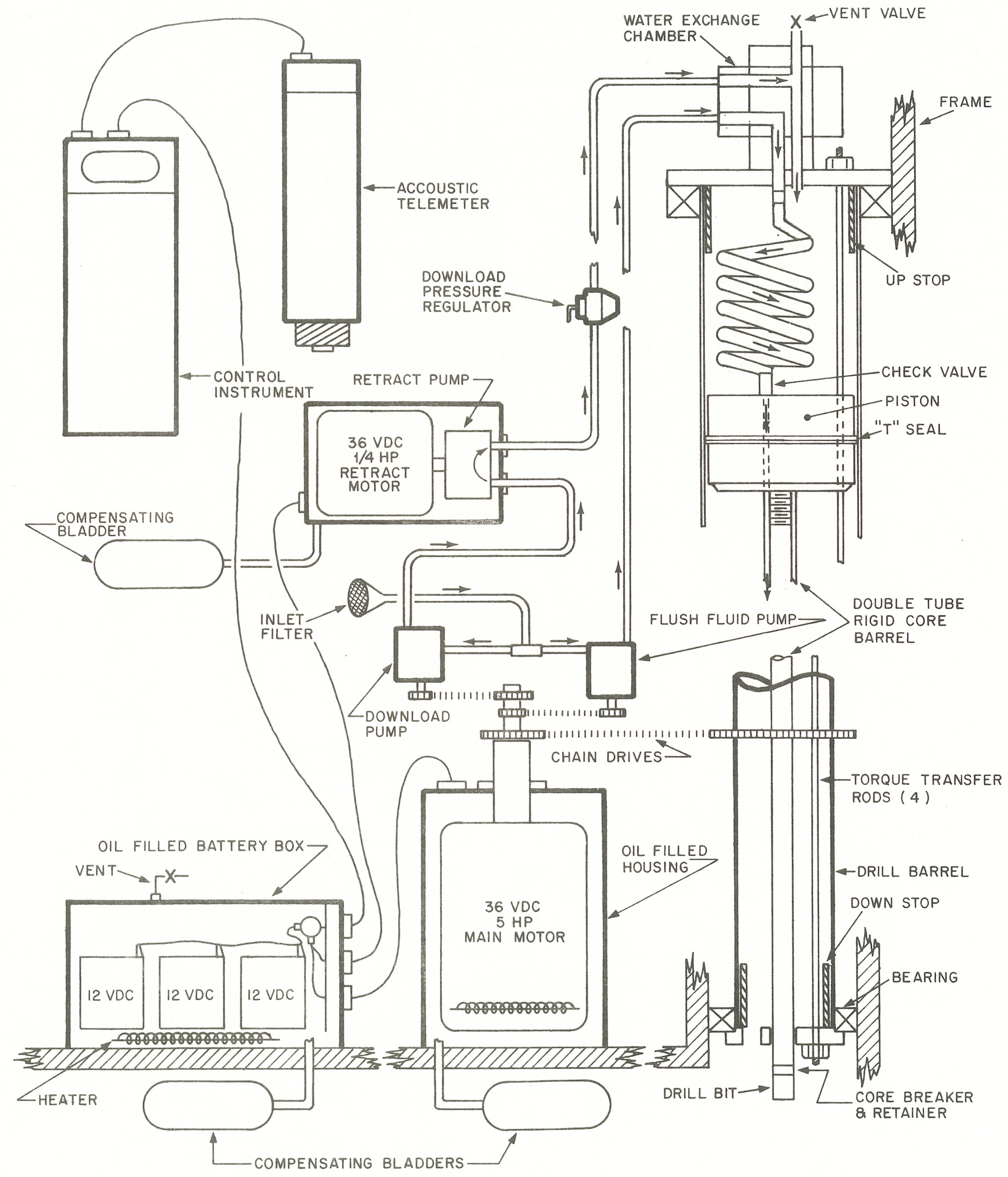

Fig. 6. Rock Drill Working Schematic. 


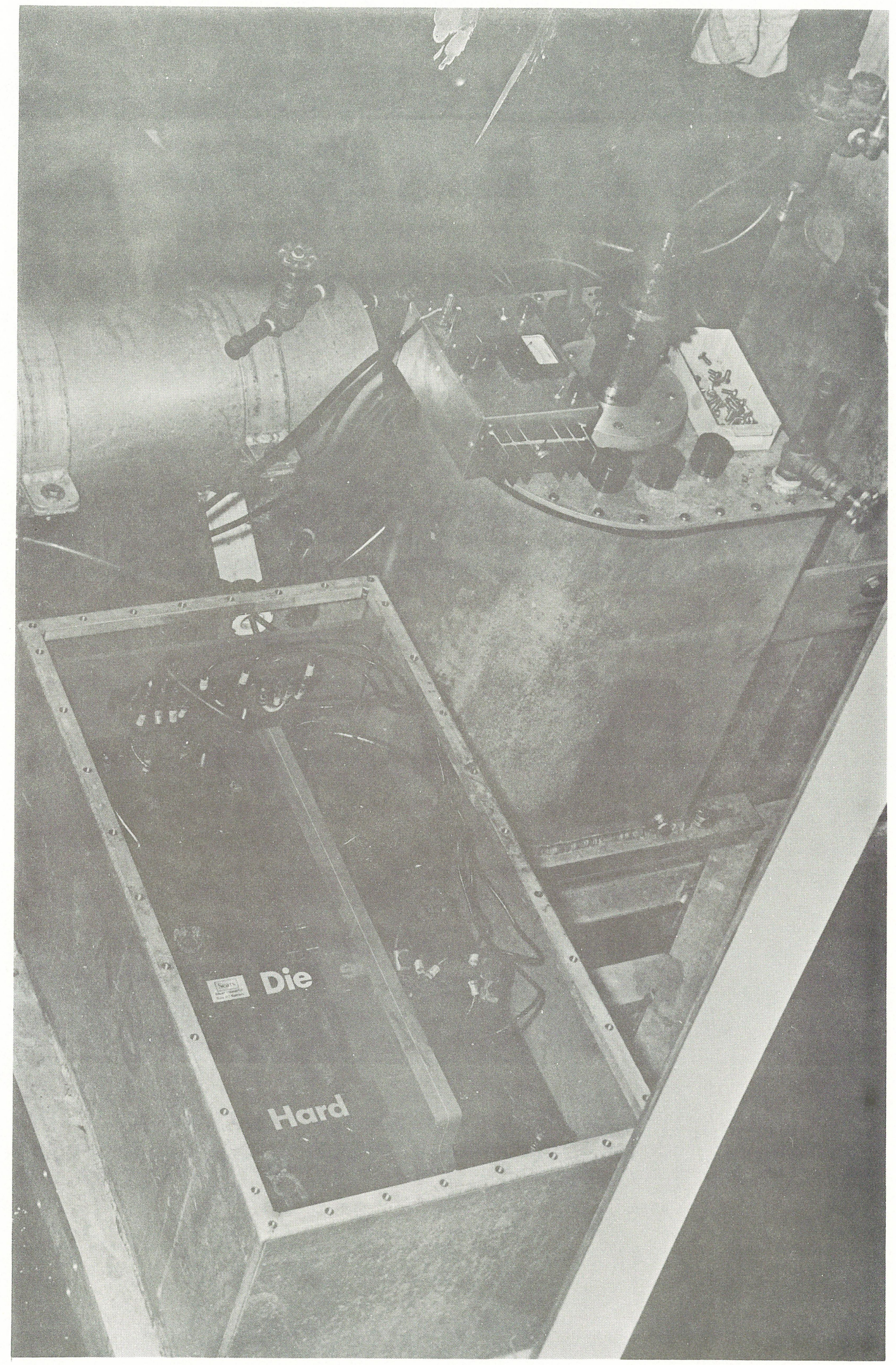

Fig. 7. Looking down into the main battery box, showing three automobile wet cells and the solenoid and main wiring bus at the upper left. 


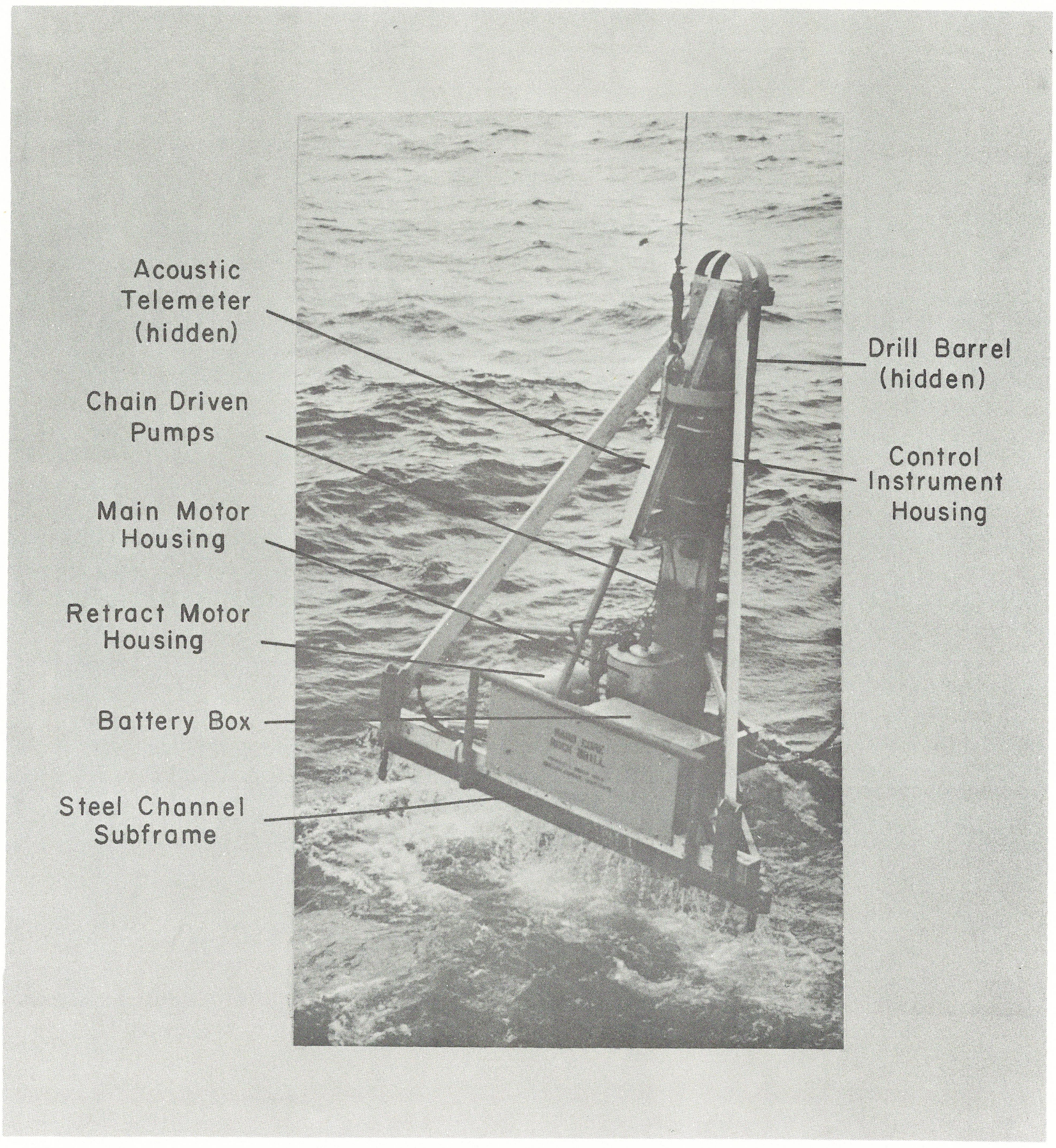

Fig. 8a. The rock drill with its major components labeled. Note the protective structure. 


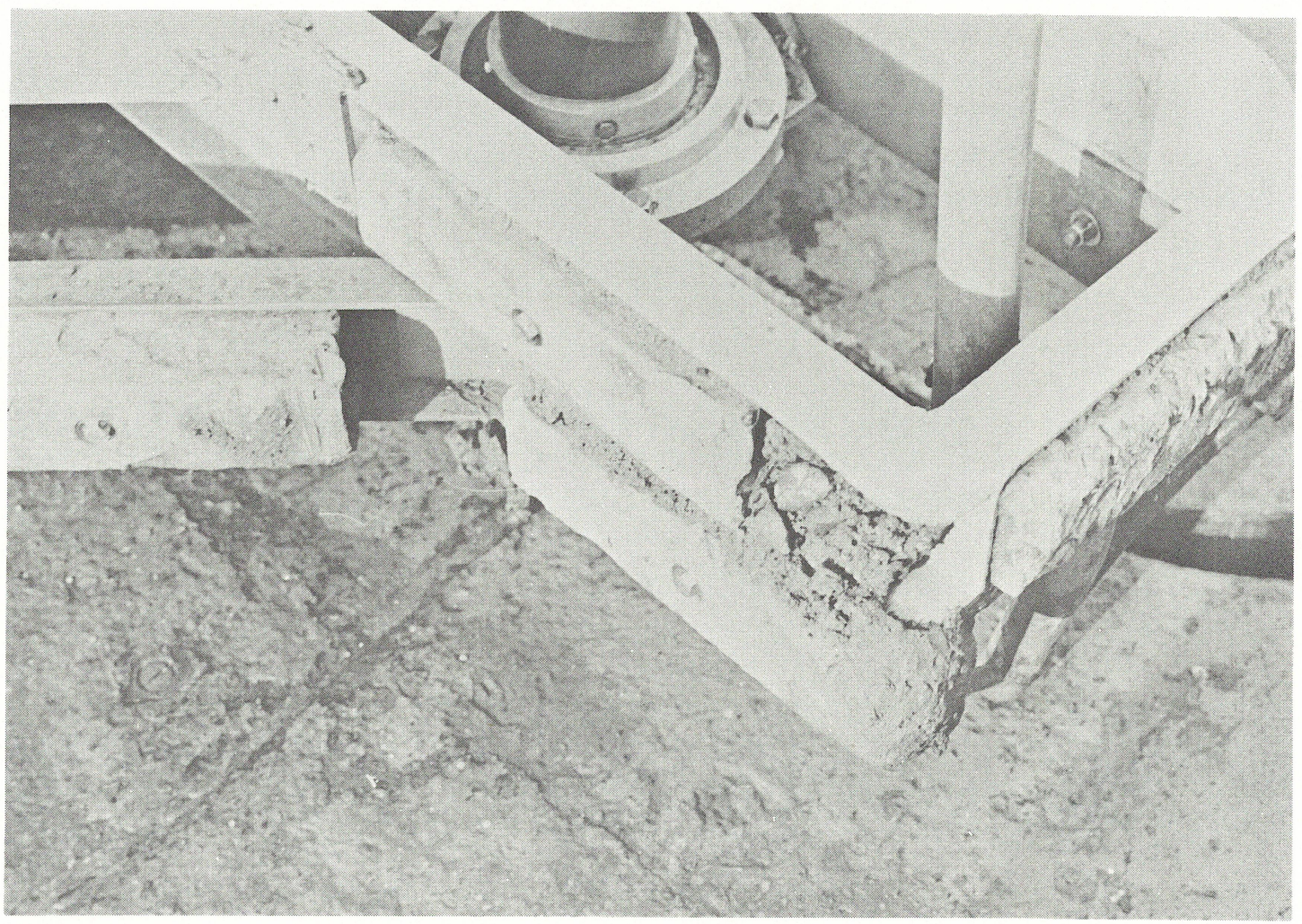

Fig. 8b. A close-up of the forward section with attached lead ballasting. 


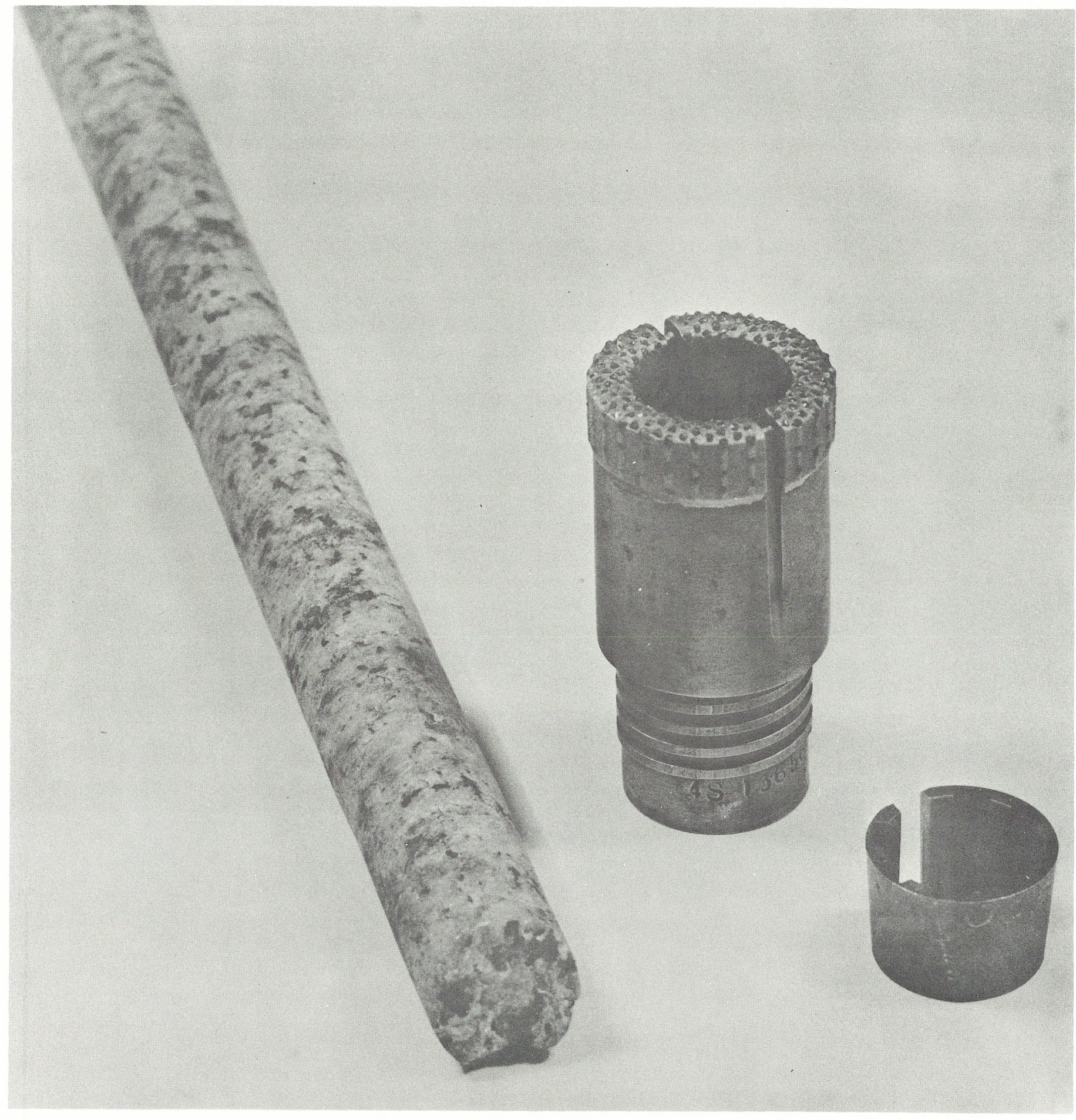

Fig. 9. This close-up of a 100 stone per carat XRT bit shows the individual diamonds and cooling fluid channels. The lifter spring at the right grips the core during recovery. A 3/4-inch diameter granodiorite core is at the left. 


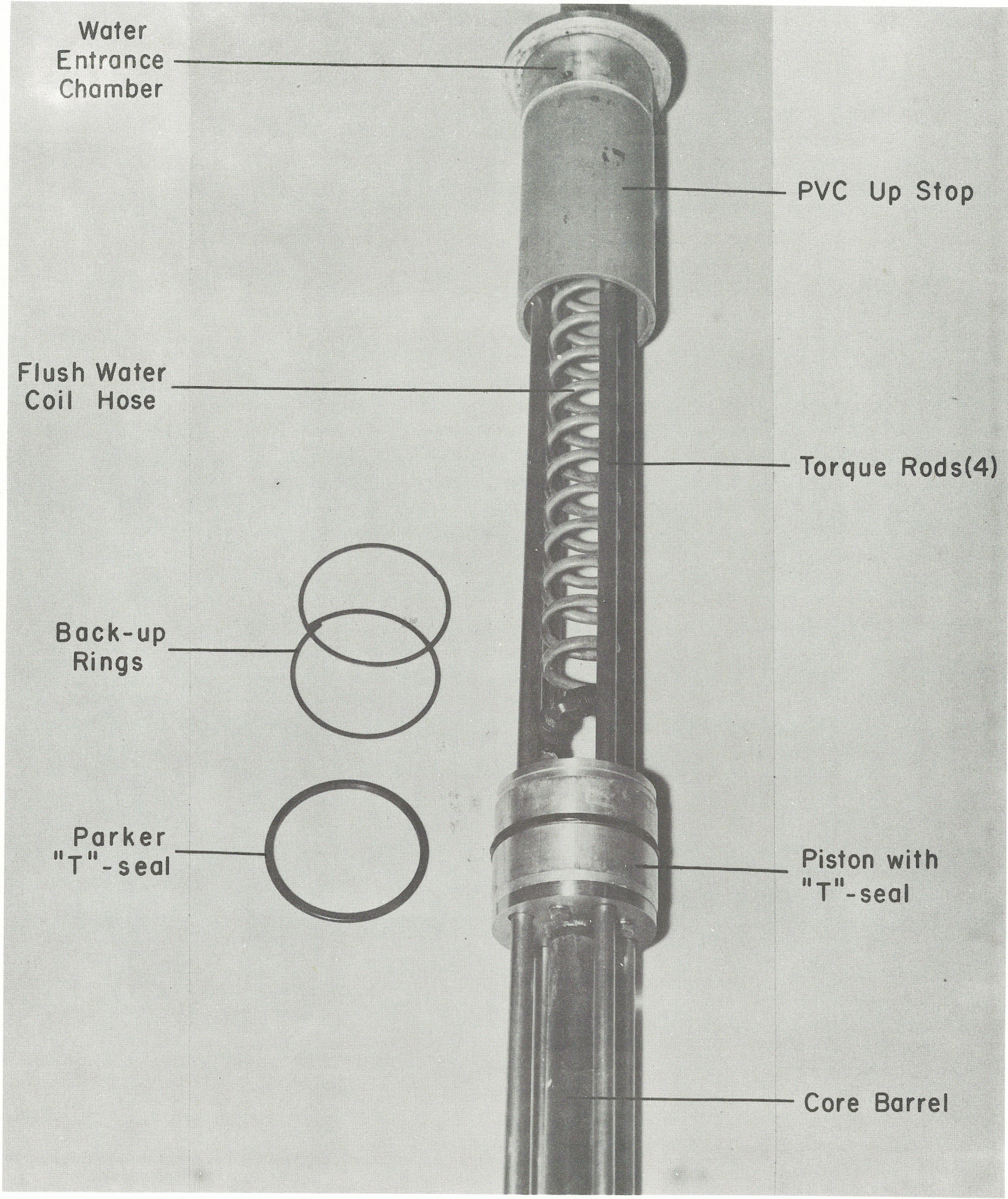

Fig. 10. "T"-seal and piston assembly. Shown with a Parker "T"-seal installed, the assembled piston, flush fluid coil hose above, the four torque rods, and core barrel below. 


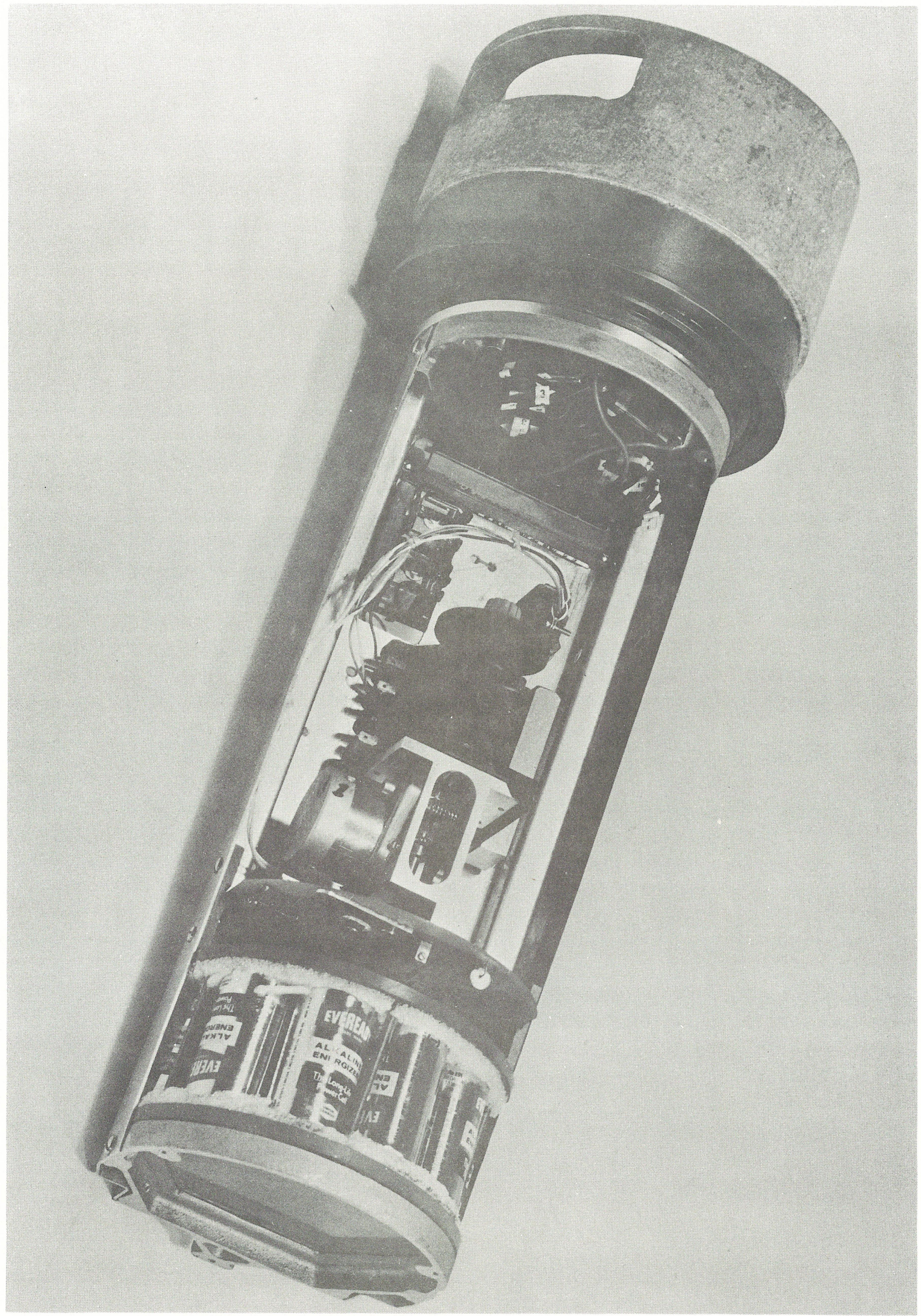

Fig. 11. The present control instrument uses 13 alkaline "D" cells to power a 12 VDC motor which in turn drives the geared timer (center). The end cap at the top, with radial and face sealing "0"-rings mates with the pressure case housing attached to the drill frame. 


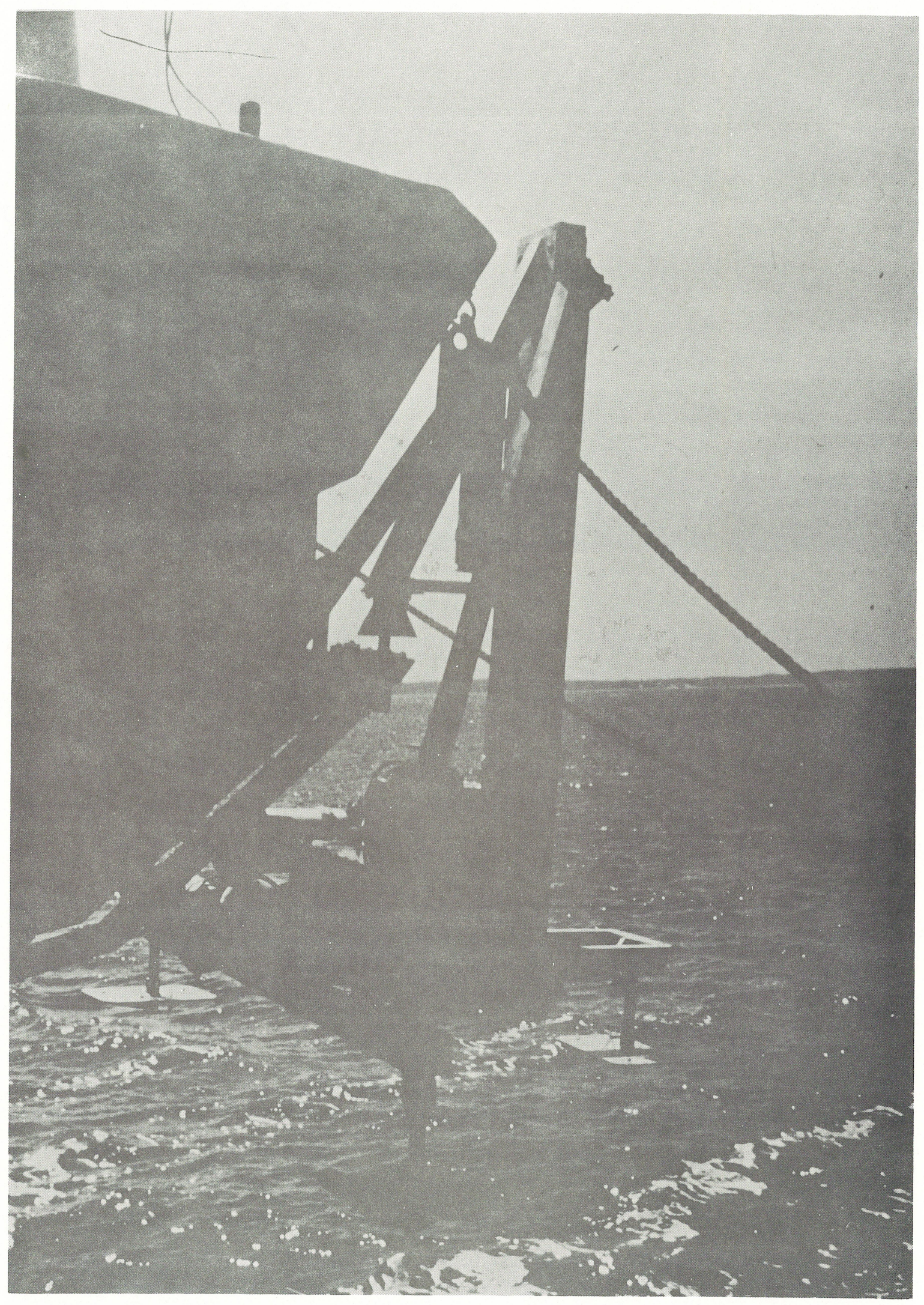

Fig. 12. The drill mated to ALVIN during transit to a dive site. Note attachment hardware. 


\section{PENETRATION}

VS.

TIME - IN BASALT AT 550 RPM, 550 lbs. DL

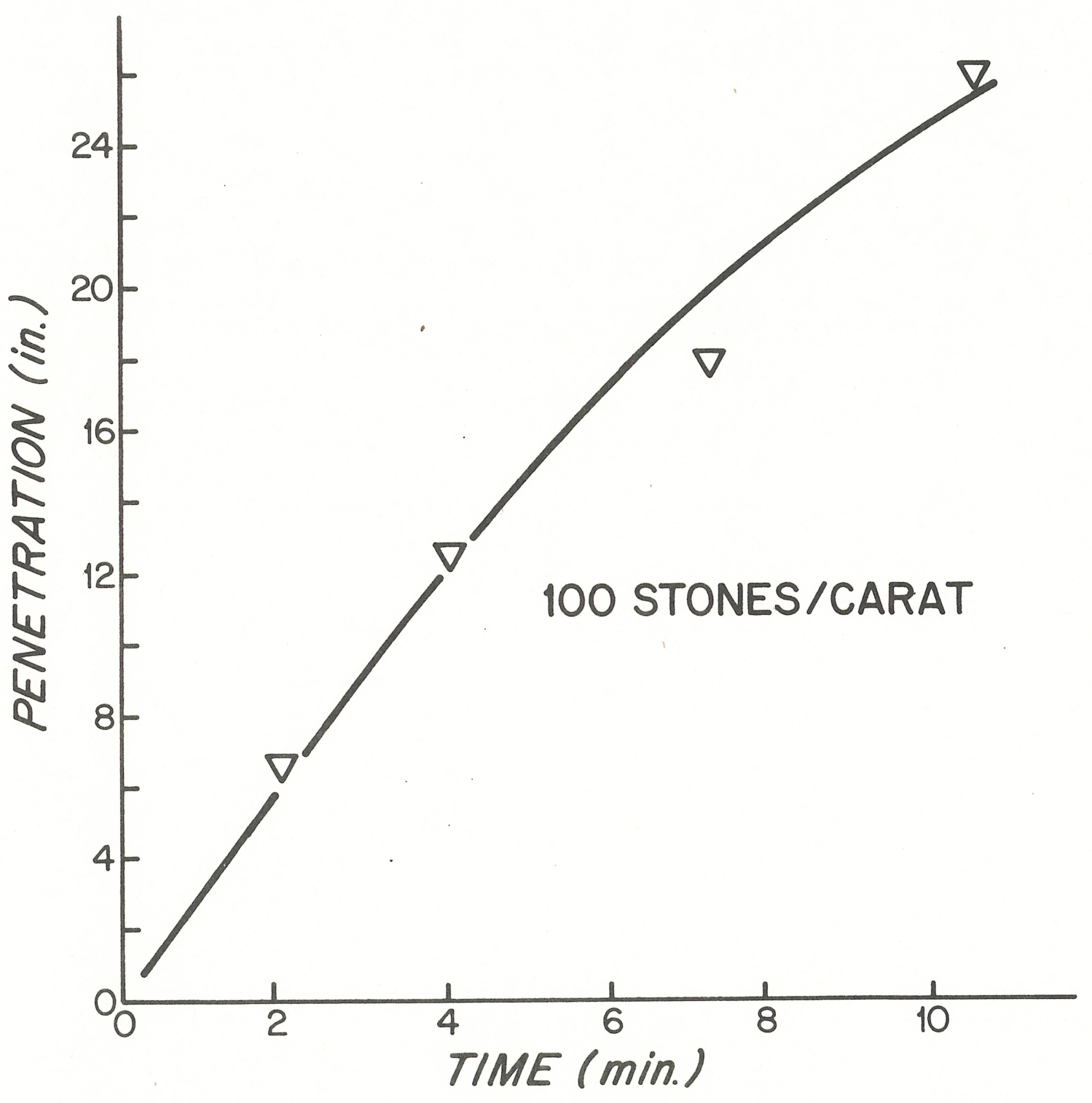

AVERAGE PENETRATION RATE: $>21 / 2$ INCHES PER MINUTE (26 INCHES DRILLED IN 10 MIN. ON 4 DIFFERENT RUNS WITH SAME BIT.)

Graph 1 . 


\section{PENETRATION}

vs.

TIME - IN GRANITE AT 550 RPM, 550 lbs. DL

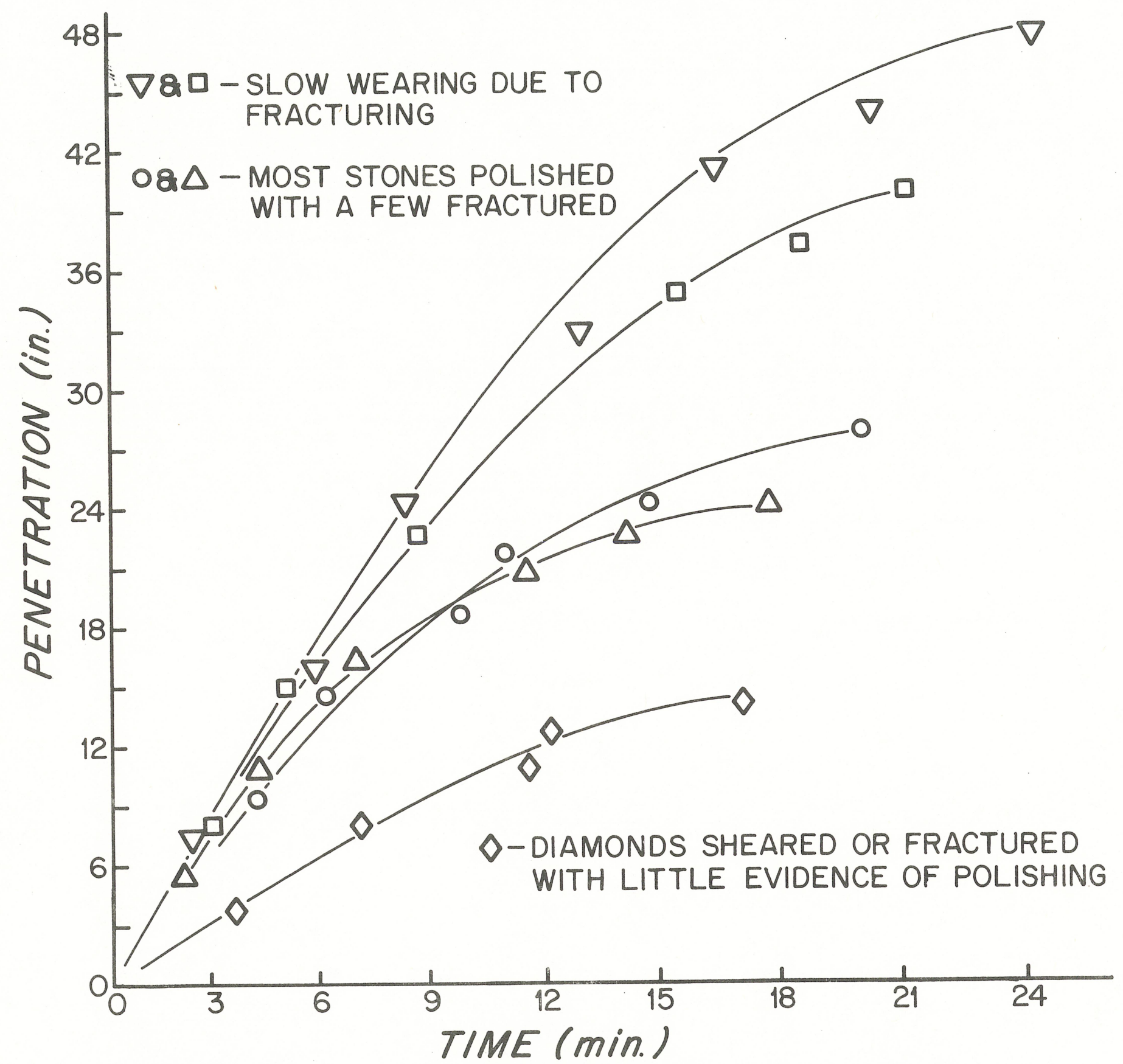

KEY: $\nabla 100$ STONES CARAT, 3K TOTAL WEIGHT, PREMIUM STONES 口 60 STONES CARAT, 3K TOTAL WEIGHT, PREMIUM STONES

$\triangle 40$ STONES CARAT, $3 \mathrm{~K}$ TOTAL WEIGHT, SELECT STONES

- 25 STONES CARAT, $3 K$ TOTAL WEIGHT, SELECT STONES

$\checkmark 2 O$ STONES CARAT, $2 K$ TOTAL WEIGHT, SELECT STONES 
PENETRATION RATE vs. DOWNLOAD - in Granite for $20,25,40,60 \& 100$ stones/carat XRT bits

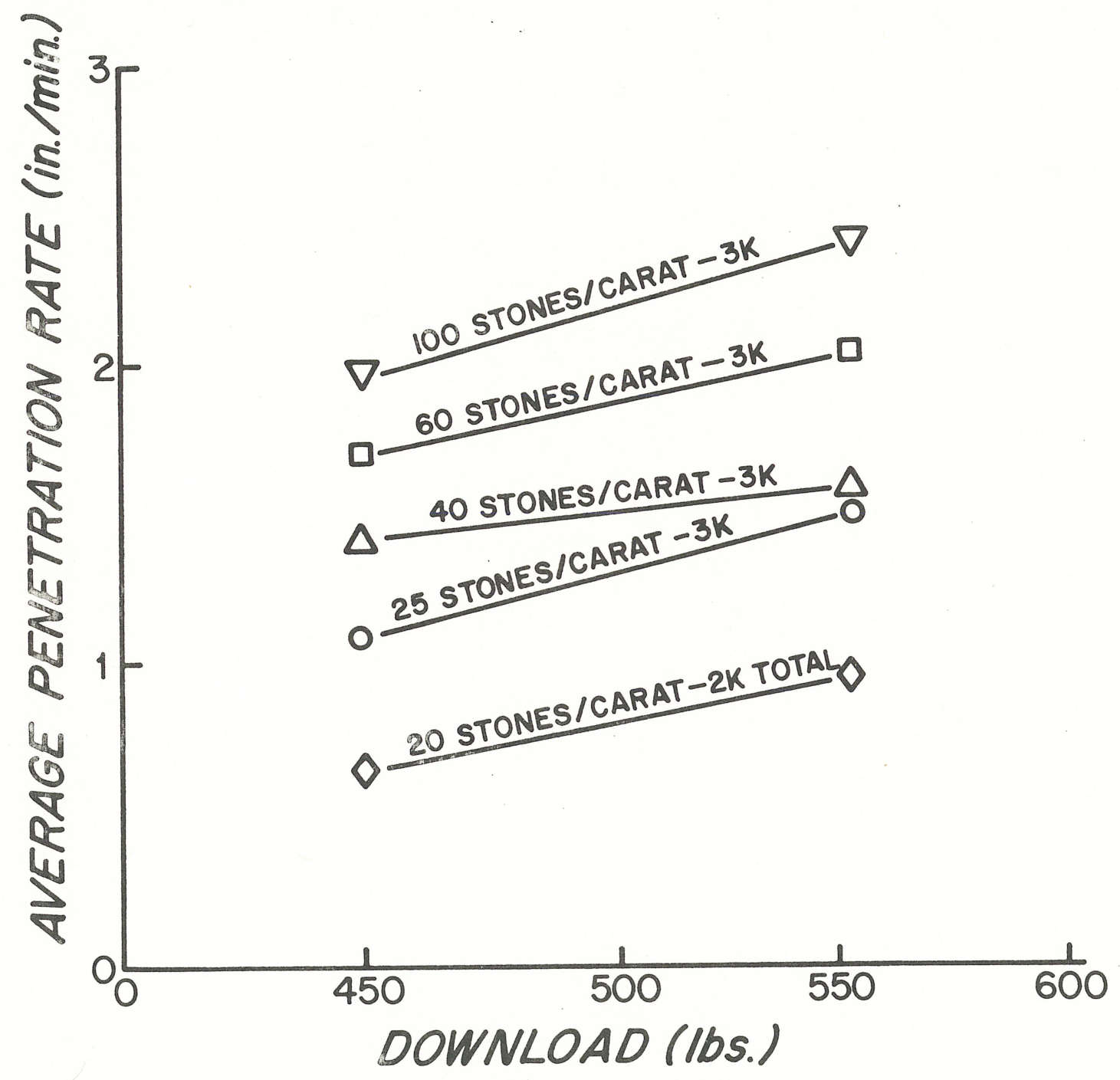

550-575 RPM

Graph 3 . 


\section{DISTRIBUTION LIST}

Director

Advanced Research Projects Agency

1400 Wilson Boulevard

Arlington, VA 22209

Attn: Program Management

Romote Area Conflict Information Center

Battelle Memorial Institute

505 King Avenue

Columbus, $\mathrm{OH} \quad 43201$

Strategic Technology Office

Information Analysis Center

Battelle Memorial Institute

505 King Avenue

Columbus, $\mathrm{OH} \quad 43201$

Office of Naval Research

800 North Quincy Street

Arlington, VA 22217

Code 105

Commandant, USMC (Code RD-1) 1

Washington, DC 20380

NUSC (Library)

NUC San Diego

SUBDEVGRU ONE, San Diego 


\section{MANDATORY DISTRIBUTION LIST}

FOR UNCLASSIFIED TECHNICAL REPORTS, REPRINTS, \& FINAL REPORTS PUBLISHED BY OCEANOGRAPHIC CONTRACTORS

OF THE OCEAN SCIENCE AND TECHNOLOGY DIVISION OF THE OFFICE OF NAVAL RESEARCH

(REVISED JAN 。 1975)

1 Director of Defense Research and Engineering

Office of the Secretary of Defense Washington, DC 20301

ATTN: Office Assistant Director (Research)

Office of Naval Research

Arlington, VA 22217

3 ATTN: (Code 480)

1 ATTN: (Code 460)

1 ATTN: (Code 102-OS)

6 ATTN: (Code 102IP)

1 LCDR David Cacchione, (USN)

ONR Representative

Woods Hole Oceanographic Inst.

Woods Hole, MA 02543

1 Office of Naval Research

Branch Office

495 Summer Street

Boston, MA 02210

Director

Naval Research Laboratory

Washington, DC 20375

6 ATTN: Library, Code 2620

1 National Oceanographic Data Center

National Oceanic \& Atmospheric

Administration

Washington, DC 20235
12 Defense Documentation.

Center

Cameron Station

Alexandria, VA 22314

Commander

Naval Oceanographic

Office

Washington, DC 20390

1 ATTN: Code 1640

1 ATTN: Code 70 


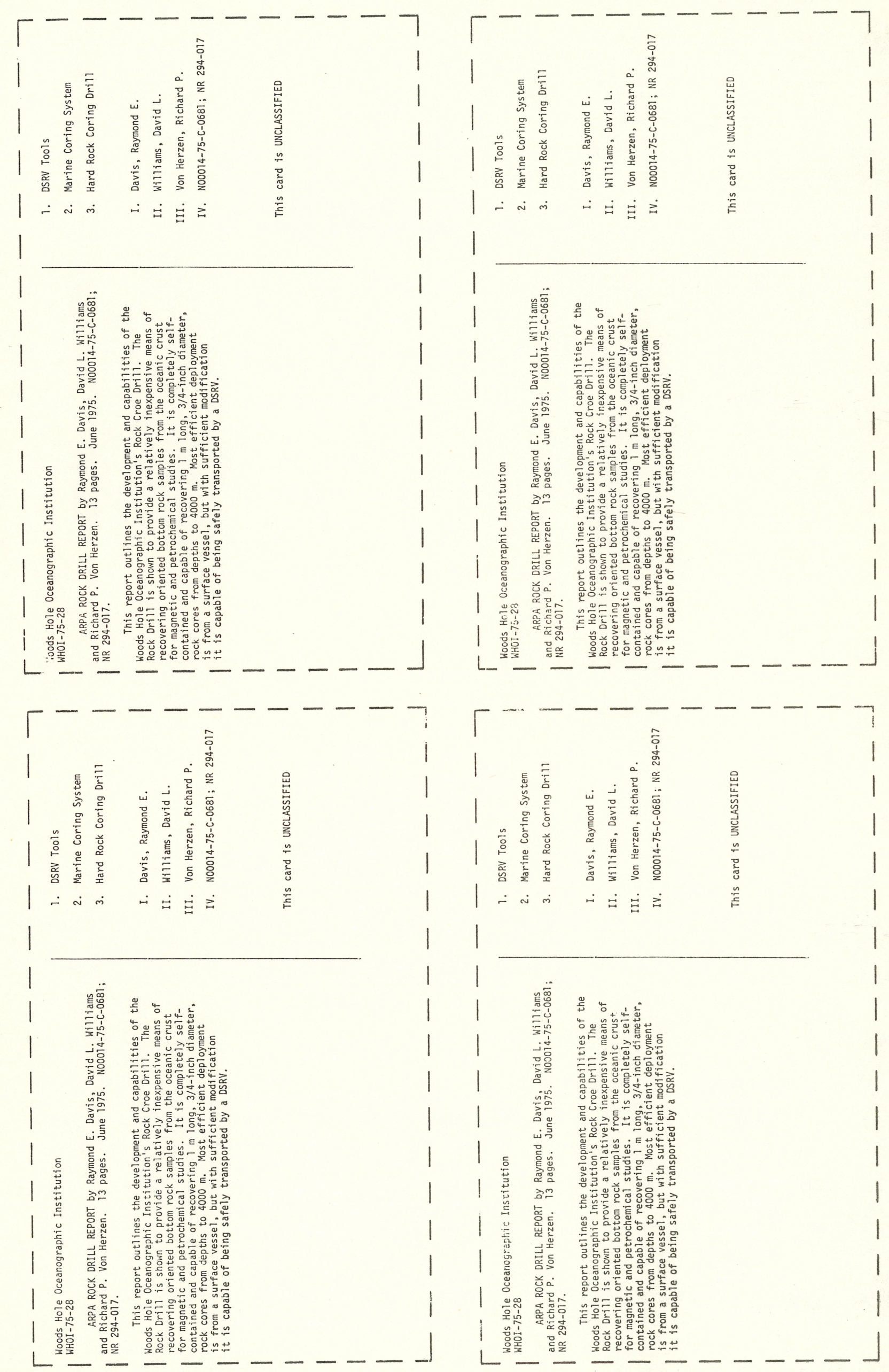


SECURITY CLASSIFICATION OF THIS PAGE (When Dato Entored)

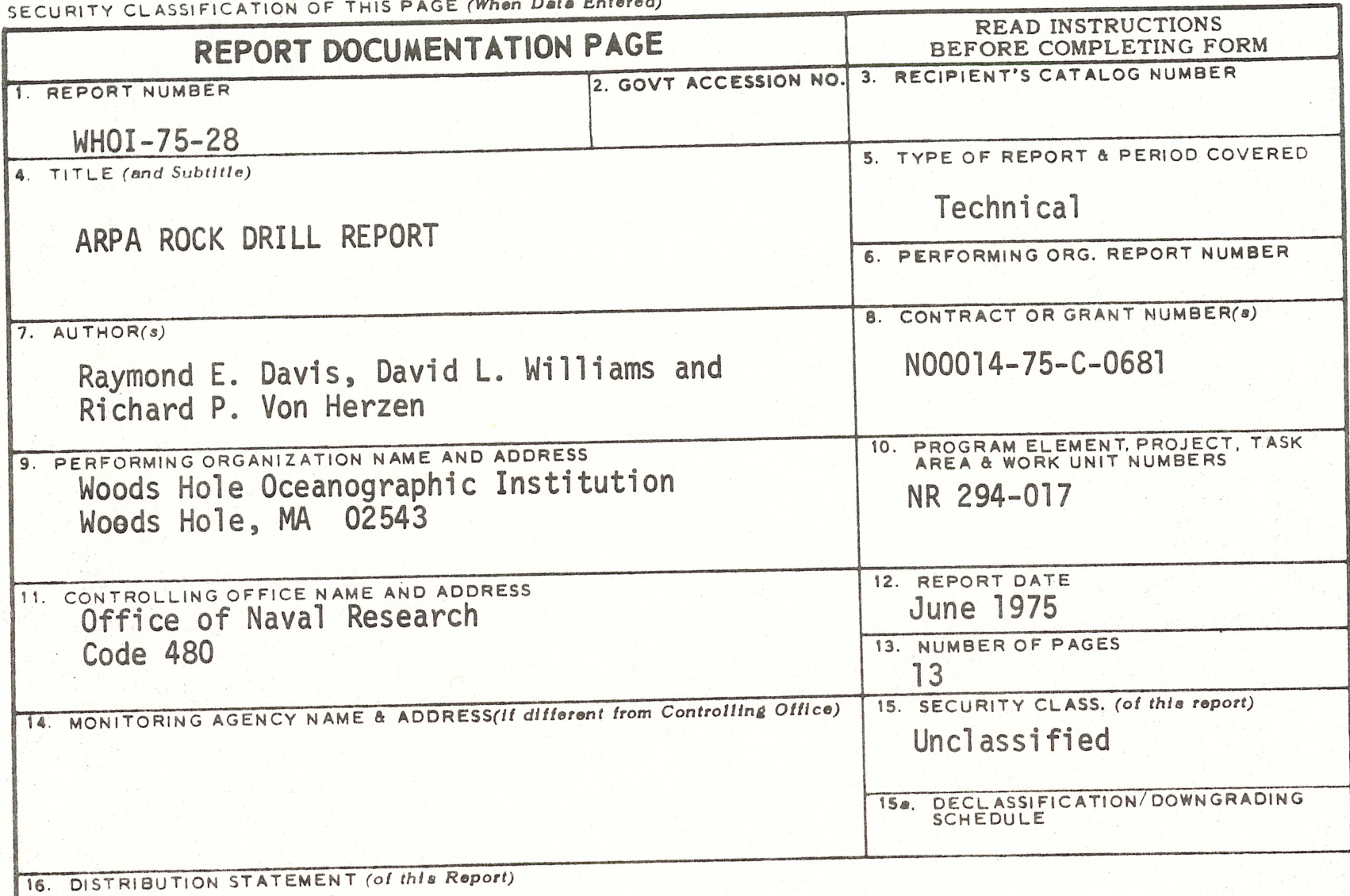

Approved for public release; distribution unlimited.

17. DISTRIBUTION STATEMENT (of the abstract ontered In Block 20, if different from Roport)

18. SUPPLEMENTARY NOTES

19. KEY WORDS (Continue on roverse ldo il noceesary and ldentlfy by block number)

1. DSRV Tools

2. Marine Coring System

3. Hard Rock Coring Drill

20. ABSTRACT (Conthue on peverse olde if neceseary and identify by block number)

This report outlines the development and capabilities of the Woods Hole Oceanographic Institution's Rock Core Dri11. The Rock Drill is shown to provide a relatively inexpensive means of recovering oriented bottom rock samples from the oceanic crust for magnetic and petrochemical studies. It is completely self-contained and capable of recovering $1 \mathrm{~m}$ long, 3/4-inch diameter, rock cores from depths to $4000 \mathrm{~m}$. Most efficient deployment is from a surface vessel, but with sufficient modification it is capable of being safely transported by a DSRV.

DD, JUMT 73473 EDITION OF I NOV 65 IS OBSOLETE $\mathrm{S} / \mathrm{N} 0102.014 .660$ 
